\title{
Vessel Dimensions in Premature Atheromatous Disease of Aortic Bifurcation
}

\author{
R. C. LALLEMAND, K. G. E. BROWN, P. S. BOULTER
}

British Medical fournal, 1972, 2, 255-257

\section{Summary}

The area ratio of the abdominal aortic bifurcation is defined as the ratio of the sum of the cross-sectional areas of the common iliac arteries to the cross-sectional area of the aorta. Abnormality of the area ratio is associated with initiation of atheroma of the lower aorta. Hypoplasia of the abdominal aorta predisposes to early occlusion as the atheromatous process advances.

In five out of six women with thrombosis at the aortic bifurcation the area ratio was low. Hypoplasia of the abdominal aorta was present in two of these patients. All six patients were successfully treated by aortoiliac disobliteration and reconstruction.

\section{Introduction}

Atheromatous change tends to be most severe at those points where the vessel wall is exposed to damage by additional haemodynamic stress. Arterial bifurcations are a frequent site of localized atheroma-the stress occurs when a sufficient proportion of the pulse wave is reflected from the bifurcation, setting up a standing wave of pressure proximal to the point of reflection. Womersley (1958) showed on theoretical grounds that the proportion of a pulse wave that is reflected by a bifurcation depends on the "area ratio"-that is, the ratio of the sum of the cross-sectional areas of the branches to the crosssectional area of the parent vessel.

Gosling et al. (1971) calculated that reflection will be minimal when the ratio is 1.15 and that the proportion reflected (and the size of the standing pressure wave) will increase progressively with any divergence from that "ideal" value (see Chart). They also showed by aortography in subjects apparently free from vascular disease that in human infants the area ratio for the aortic bifurcation is, in fact, very close to the ideal value. With increasing age, however, it falls progressively, so that by age 45

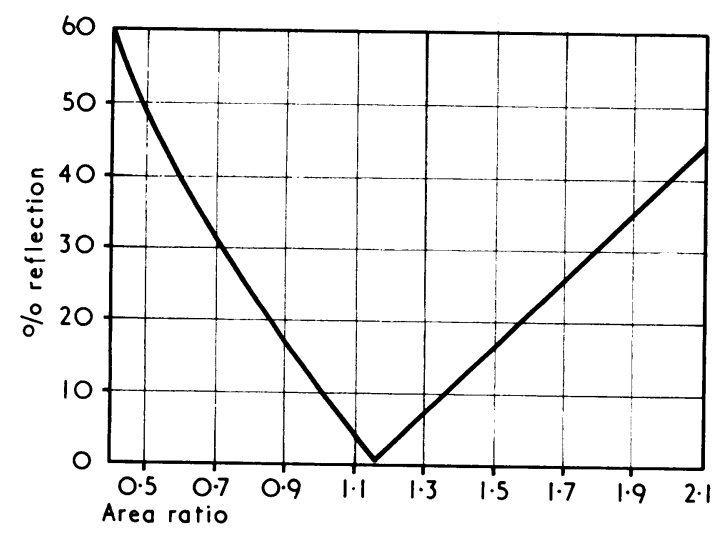

Effect of area ratio on reflection of incident pulse wave at aortic bifurcation (Gosling et al., 1971).

Royal Surrey County Hospital, Guildford, Surrey

R. C. LALLEMAND, F.R.C.S., Surgical Registrar

K. G. E. BROWN, M.R.C.P., House Surgeon

P. S. BOULTER, F.R.C.S., Honorary Consultant Surgeon

the "normal" value becomes 0.75 with theoretical reflection of $25 \%$ of the incident pulse wave from the bifurcation. No such age-related change could be shown in animals; Gosling et al. suggested that this increasing "mismatching" of the aortic-iliac junction with age in man and the correspondingly enhanced oscillatory stress components in the aortic wall play an important part in the atherogenesis at and above the bifurcation in the elderly.

When atheroma localized to the bifurcation of the aorta occurs at a relatively early age in a patient with no evidence of generalized atherosclerosis it seems reasonable to suspect that an excessive stress factor has operated at this point. We have therefore measured the dimensions of the abdominal aorta and iliac arteries in six women who presented in early middle age with localized atheroma and thrombosis at the aortic bifurcation requiring surgical treatment.

\section{Present Series}

The history and findings in the six women, who presented with symptoms of lower limb ischaemia, are summarized in Table I. All were premenopausal. None were taking hormonal contra-

\begin{tabular}{|c|c|c|c|c|c|}
\hline & $\begin{array}{l}\text { Case } \\
\text { No. }\end{array}$ & $\begin{array}{c}\text { Age } \\
\text { (Years) }\end{array}$ & $\begin{array}{l}\text { Presenting } \\
\text { Symptoms }\end{array}$ & Findings & $\begin{array}{c}\text { Postoperative } \\
\text { Result }\end{array}$ \\
\hline 1 & $\ldots$ & 45 & $\begin{array}{l}\text { Gangrenous left } \\
\text { foot. Pregangrene } \\
\text { right foot. } \\
\text { Bronchopneu- } \\
\text { monia }\end{array}$ & $\begin{array}{l}\text { Aortic occlusion. } \\
\text { Hypertensive } \\
\text { retinopathy. } \\
\text { B.P. 210/105 }\end{array}$ & $\begin{array}{l}\text { Unlimited walking } \\
\text { with artificial } \\
\text { limb }\end{array}$ \\
\hline 2 & . & 45 & $\begin{array}{l}\text { Bilateral thigh } \\
\text { pain on walking } \\
75 \text { yards }(60 \mathrm{~m})\end{array}$ & $\begin{array}{l}\text { Incomplete aortic } \\
\text { thrombosis }\end{array}$ & $\begin{array}{l}\text { Walking distance } \\
\text { unlimited }\end{array}$ \\
\hline 3 & .. & 44 & $\begin{array}{l}\text { Bilateral thigh } \\
\text { pain on walking } \\
50 \text { yards }(45 \mathrm{~m}) \text {. } \\
\text { Right worse than } \\
\text { left }\end{array}$ & $\begin{array}{l}\text { Incomplete aortic } \\
\text { thrombosis. } \\
\text { Complete right } \\
\text { iliac thrombosis }\end{array}$ & $\begin{array}{l}\text { Walking distance } \\
1 \text { mile }(1 \cdot 6 \mathrm{~km}) \text {. } \\
\text { Peripheral vessels } \\
\text { patent }\end{array}$ \\
\hline 4 & .. & 45 & $\begin{array}{l}\text { Bilateral thigh } \\
\text { pain on walking } \\
50 \text { yards }(45 \mathrm{~m}) \text {. }\end{array}$ & $\begin{array}{l}\text { Incomplete aortic } \\
\text { thrombosis }\end{array}$ & $\begin{array}{l}\text { Walking distance } \\
\text { unlimited }\end{array}$ \\
\hline 5 & . & 36 & $\begin{array}{l}\text { Bilateral buttock } \\
\text { pain on walking } \\
25 \text { yards }(23 \mathrm{~m})\end{array}$ & $\begin{array}{l}\text { Aortic occlusion. } \\
\text { Popliteal B.P. } \\
\text { (mm Hg): } \\
\text { R. 64, L. } 70\end{array}$ & $\begin{array}{l}\text { Walking distance } \\
\text { unlimited. } \\
\text { Popliteal B.P. } \\
\text { (mm Hg): }\end{array}$ \\
\hline 6 & .. & 51 & $\begin{array}{c}\text { Bilateral buttock } \\
\text { pain on walking } \\
50 \text { yards }(45 \mathrm{~m})\end{array}$ & $\begin{array}{l}\text { Incomplete aortic } \\
\text { thrombosis }\end{array}$ & $\begin{array}{l}\text { Walking distance } \\
\text { unlimited }\end{array}$ \\
\hline
\end{tabular}

ceptives (Hall and Bunch, 1971) and only one (Case 1) was a cigarette smoker. Five patients presented with ischaemic muscle pain on exercise. One patient was admitted with a gangrenous left leg, in a toxic confusional state, and with bronchopneumonia. Early sympathectomy and amputation were performed on this patient. The onset of ischaemic change in the remaining foot led to further investigation and treatment.

Translumbar aortography was carried out before operation in all cases. Varying degrees of narrowing and irregularity at the aortic bifurcation were found. No other manifestations of atheroma were shown, and the electrocardiograms and serum cholesterol levels were normal.

Operative technique consisted in disobliteration of the bifurcation through separate longitudinal arteriotomies in the aorta and common iliac arteries. The aorta was reconstructed with a gusset of Teflon and the iliac arteries with saphenous vein patches.

All patients made a satisfactory recovery with improved 
exercise tolerance, and the amputee returned to almost normal life with an artificial limb.

\section{VESSEL DIMENSIONS}

Caliper measurement of the external diameter of the vessels was made at operation (Table II). Measurements at the bifurcation

TABLE II-External Diameter of Vessels measured at Operation

\begin{tabular}{|c|c|c|c|c|}
\hline $\begin{array}{l}\text { Case } \\
\text { No. }\end{array}$ & $\begin{array}{c}\text { Aorta at } \\
\text { Renals }\end{array}$ & $\begin{array}{c}\text { Aorta at } \\
\text { Bifurcation }\end{array}$ & $\begin{array}{c}\text { Common } \\
\text { Iliac }\end{array}$ & $\begin{array}{l}\text { Area } \\
\text { Ratio }\end{array}$ \\
\hline $\begin{array}{ll}1 & \ldots \\
2 & \cdots \\
3 & \cdots \\
4 & \cdots \\
5 & \cdots \\
6 & \cdots\end{array}$ & $\begin{array}{l}20 \mathrm{~mm} \\
18 \mathrm{~mm} \\
15 \mathrm{~mm} \\
19 \mathrm{~mm}\end{array}$ & $\begin{array}{l}14 \mathrm{~mm} \\
14 \mathrm{~mm} \\
12 \mathrm{~mm} \\
13 \mathrm{~mm} \\
8 \mathrm{~mm} \\
13 \mathrm{~mm}\end{array}$ & $\begin{array}{c}6 \mathrm{~mm} \\
8 \mathrm{~mm} \\
9 \mathrm{~mm} \\
8 \mathrm{~mm} \\
4 \mathrm{~mm} \\
5 \text { and } 7 \mathrm{~mm}\end{array}$ & $\begin{array}{l}0.4 \\
0.6 \\
1.0 \\
0.7 \\
0.5 \\
0.4\end{array}$ \\
\hline
\end{tabular}

were taken with the aorta clamped, and no attempt was made to allow for changes due to pulsation or thickening of the arterial wall. The area ratios of the aortic bifurcation were calculated from the formula

$$
\text { Area ratio }=\frac{\text { Sum of cross-sectional areas of iliac arteries }}{\text { Cross-sectional area of the aorta }}
$$

Since the main interest was in a ratio between vessel crosssectional areas no attempt was made to relate vessel areas to body size or surface area.

\section{Discussion}

Interest in these six patients arose from their presentation in early middle age with atheroma and thrombosis at the bifurcation of the abdominal aorta. The area ratio in five of them (Table II) was less than the normal of 0.75 found by Gosling et al. (1971) for their age. Their area ratios would be compatible with a reflection of the incident pulse wave between $25 \%$ and $60 \%$ (see Chart).

Reflection of the pulse wave from the aortic bifurcation sets up a partial standing wave of pressure in the lower aorta with the antinode at the bifurcation. Stress due to oscillatory pressure on the wall of the lower aorta increases with percentage reflection and damage to the vessel wall becomes likely.

Payling Wright (1968) showed that there is an increased mitotic rate among endothelial cells at arterial junctions in the aorta of healthy guinea-pigs. Of great interest is her finding that the same phenomenon occurs proximal to and at the site of an artificially produced aortic narrowing, whereas endothelial cell mitosis is normal beyond the narrowing. She also showed that the half-life of endothelial cells at these sites is shorter than usual (Payling Wright, 1970). Atheromatous change proximal to sites of coarctation has been reported (Pyorala et al., 1960). These phenomena could be explained by the hypothesis that endothelial cell damage is due to increased oscillatory pressures in the lower aorta set up by the partial standing wave.

In two of the present patients (Cases 3 and 5) the aorta was narrow from just below the renal arteries to the bifurcation. The iliac vessels were also narrow (Table II). The abdominal aorta may have a narrow segment of $1-3 \mathrm{~cm}$ in length or be generally hypoplastic (D'Abreu et al., 1959). Patients with segmental narrowing (coarctation) have a prominent collateral circulation and usually present before the age of 30 . Segmental narrowing of the abdominal aorta may be associated with coarctation of the thoracic aorta (Wood, 1956).

In the hypoplastic group the aorta becomes narrow at a certain point and remains narrow down to the bifurcation. Collateral circulation is less developed and presentation is at a later age, with complications due to atheromatous occlusive disease. The two patients with narrow abdominal aortas fall into this latter group. The diameter at the aortic bifurcation in both cases was less than $12.5 \mathrm{~mm}$, the measurement suggested by Clemetson (1960) as the lower limit of normal. There is an obvious limitation in accepting an absolute measurement which has not been related to other criteria of body size. None of these patients had segmental narrowing of the abdominal aorta.

Hypoplasia of the whole aorta may be asymptomatic (Werley et al., 1944) but has been suggested as a cause of sudden death in young adults (Laurie, 1968). Other features associated with hypoplasia of the aorta in the literature are premature heart failure (Burke, 1902; Pyorala et al., 1959), hemiplegia (Valentine and Nicholl, 1945) and mental retardation (Pyorala et al., 1959), ischaemic renal vascular lesions (Fisher and Corcoran, 1952; Brust and Ferris, 1957; Immon and Pollock, 1956; Magyar et al., 1968), absence of aortic knuckle on chest $x$-ray examination (Stoerk, 1912), narrowing of retinal vessels (Von Ritock, 1907), and recurrent severe pre-eclamptic toxaemia of pregnancy (Clemetson, 1960).

The six patients in this series presented with premature atheroma and thrombosis at the aortic bifurcation. None showed any of the phenomena of generalized atheromatous disease usually seen in older patients, nor was there evidence of features associated with hypoplasia mentioned in the literature above. In five the area ratio was abnormally low for their age. We believe that this was a major factor initiating deposition of atheroma in the aortic wall. Hypoplasia of the abdominal aorta in these patients might be expected to predispose to earlier occlusion. In one of the five patients with an abnormally low area ratio (Case 5) hypoplasia of the abdominal aorta was also present. It may be significant that she presented at a younger age than the others. In another patient (Case 3 ) the area ratio was normal, but hypoplasia of the abdominal aorta was present and appeared to be the sole cause for her early presentation. Of these two patients with hypoplasia of the abdominal aorta the area ratio was low in one and normal in the other. This suggests that hypoplasia and a low area ratio are not necessarily associated.

All measurements were made in vessels with occlusive atheromatous disease and with a proximal aortic clamp applied. Occlusive thrombus may in its own right cause narrowing of the aorta. Systemic arterial pressure, however, distends the aorta more than the iliac arteries, and at a physiological pressure the area ratios would be even lower than those calculated from our measurements.

Segmental aortic narrowing has been treated by resection or by a bypass procedure (Doberneck and Varco, 1968). When the distal artery is hypoplastic obliterative aortoiliac disease is treated by endarterectomy or bypass (Debakey et al., 1958; Cockett and Maurice, 1963; Clarke and Provan, 1969). Anastomosis with a bypass may be difficult and has been regarded as a contraindication to operation (D'Abreu et al., 1959). Our experience illustrates that by using the technique of disobliteration with aortoplasty perfusion of the distal arterial tree can be improved even where the occluded vessels and "run off" were hypoplastic.

Bypass of the aortic bifurcation will involve use of a synthetic aortic bifurcation prosthesis. Longo and Santa (1971), in discussing the ideal characteristics of such a prosthesis, suggested that the diameter of the aorta should be 1.41 times greater than that of a single iliac branch. The area ratio of this prosthesis would be 1.02 -that is, close to the ideal value of $1 \cdot 15$. This would give rise to much less reflection of the incident pulse wave (see Chart) than do prostheses in current use whose area ratio is invariably $0 \cdot 5$.

\section{References}

Brust, A. A., and Ferris, E. B. (1957). Annals of Internal Medicine, 47, 1043. Burke, J. (1902). New York State Medical fournal, 2, 286.

Clarke, R. J., and Provan, J. L. (1969). British fournal of Surgery, 58, 250. Clemetson, C. A. B. (1960). Fournal of Obstetrics and Gynaecology of the British Empire, 67, 90. 
Cockett, F. B., and Maurice, B. A. (1963). British Medical fournal, 1, 353. D'Abreu, A. L., Rob, C. G., and Vollmar, J. F. (1959). Langenbecks Archiv für klinische Chirurgie, vereinigt mit Deustche Zeitschrift für Chirurgie, $290,52$.

De Bakey, M. E., Crawford, E. S., Cooley, D. A., and Morris, G. C. (1958). Annals of Surgery, 148, 306.

Doberneck, R. C., and Varco, R. L. (1968). Lancet, 88, 143.

Fisher, E. R., and Corcoran, A. (1952). Archives of Internal Medicine, 89, 943. Gosling, R. G., Newman, D. S., Bowden, N. L. R., and Twinn, K. W. (1971). British fournal of Radiology, 44, 850.

Hall, R., and Bunch, G. A. (1971). British fournal of Surgery, 58, 508.

Immon, T. W., and Pollock, B. E. (1956). American Heart fournal, 52, 314

Laurie, W. (1968). Medical fournal of Australia, 2, 710

Longo, T., and Santa, A. (1971). Fournal of Cardiovascular Surgery, 12, 52.

Magyar, E., Veres, J., and Juhasz, J. (1968). Lancet, 2, 1351.
Pyorala, K., Keikel, P. E., and Halonen, P. I. (1959). American Heart Fournal, 67, 289.

Pyorala, K., Heinonen, O., Koskelo, P., and Keikei, P. (1960). American fournal of Cardiology, 6, 650 .

Stoerk, E. (1912). Medizinische Klinik, 8, 1227.

Von Ritock, S. (1907). Zeitschrift für klinische Medizin, 61, 32.

Valentine, N., and Nicholl, R. J. (1945). American Heart fournal, 30, 514.

Werley, G., Waite, W. W., and Kelsey, M. P. (1944). Texas State fournal of Medicine, 39, 467.

Womersley, J. R. (1958). Physics in Medicine and Biology, 2, 313.

Wood, P. (1956). Diseases of the Heart and Circulation, 2nd edn., p. 328. London, Eyre and Spottiswoode.

Wright, H. Payling (1968). Nature, 220, 78.

Wright, H. Payling (1970). Thrombosis et Diathesis Haemorrhagica, Suppl. No. 40 , p. 79.

\section{Fat Embolism in Patients with Fractured Hips}

\section{SIMON SEVITT}

British Medical fournal, 1972, 2, 257-262

\section{Summary}

Fat embolism was assessed at necropsy and correlated with clinical findings in the patients who died among 854 with fractured hips admitted to hospital between 1967 and August 1971. Sixteen cases of clinical importance were found, eight of which were judged to have been fatal or to have seriously contributed to death. Frequencies were as follows: $2 \cdot 4$ to $3 \cdot 3 \%$ among 424 patients with subcapital fractures; 0.7 to $0.8 \%$ in the 405 with trochanteric fractures; $4 \cdot 1$ to $7 \%$ among subjects treated without operation, representing $30 \%$ of those who died within seven days; and 0.9 to $1.1 \%$ among patients treated by pinning, nailing, or nail-plating. The higher frequency in the conservatively treated group is probably related to selection of poor-risk subjects. Fat embolism was found in 6.8 to $8.0 \%$ of those with subcapital fractures treated by primary Thompson's arthroplasty which utilizes acrylic cement, and in none of those given Moore's prostheses for which cement is not used. Study of a larger group after Moore's prosthesis is required to establish its lack of special risk. Fat embolism accounted for all the deaths within seven days of Thompson's arthroplasty and for most within 14 days; it was clearly related to surgery in some cases.

A possible explanation of the hazard of Thompson's arthroplasty is that fat globule entry is enhanced by a rise of intramedullary pressure due to proximal occlusion of the reamed marrow cavity. A controlled trial of the effect of venting the marrow cavity on the frequency of fat embolism is warranted. It is possible that the acrylic monomer may also contribute to venous entry of medullary fat. The higher-age group of those with subcapital fractures and associated chronic cardiac and pulmonary disease might make them more susceptible to fat embolization than those in whom arthroplasty is also carried out for chronic hip disease.

\section{Introduction}

This study* was undertaken following reports of cardiac arrest or fat embolism, or both, in patients with subcapital fractures

*For the Working Party on Acrylic Cement in Orthopaedic Surgery (Department of Health and Social Security).

Birmingham Accident Hospital, Birmingham 15

SIMON SEVITT, M.D., F.R.C.PATH., Consultant Pathologist, and Honorary Reader in Pathology, University of Birmingham during surgical replacement of the femoral head with Thompson's prosthesis. In this operation polymerizing acrylic cement (methylmethacrylate) is moulded into the reamed marrow cavity of the upper end of the femur and the stem of the titanium prosthesis is embedded therein. Some cases of cardiac arrest were associated with severe pulmonary fat embolism (Burgess 1970; Dandy 1971) or both pulmonary and systemic fat embolism (Gresham and Kuczynski, 1970; Gresham et al., 1971) and others with pulmonary thromboembolism (Phillips et al., 1971), myocardial infarction (Powell et al., 1970), or chronic heart disease. In a prospective study, Gresham et al. (1971) found five patients with fatal fat embolism, including two who died on the operating table, among 32 with subcapital fractures subjected to Thompson's arthroplasty. However, neither fat embolism nor cardiac arrest has been reported after arthroplasty with Moore's prosthesis, for which acrylic cement is not ordinarily used, and few cases have been reported after total hip replacement for chronic arthritic disease with prostheses in which cement is used (Charnley et al., 1971).

Fatal fat embolism has also occurred after prosthetic operations on the knee, with or without the use of cement (Harris, 1970; Norcross, personal communication). Consequently the role of the cement is uncertain. Acute hypotension is also not infrequent during prosthetic hip operations involving the use of cement (Frost, 1970; Powell et al., 1970; Phillips et al., 1971). The origin of the cardiac symptoms and their possible relation to the operation, potential toxicity of the monomer used to polymerize the cement, fat embolism, and natural disease in these elderly subjects are not fully resolved.

This study attempts to assess the risks of fat embolism in patients with various hip fractures, with emphasis on the role of arthroplasty. Assessing the risk of fat embolism and comparing the risks in different groups require strict criteria. Clinical diagnosis was not used, since often it is inaccurate and many diagnoses are overlooked (Sevitt, 1962). Consequently, the assessments were based primarily on a histological search for fat emboli at necropsy. Positive results were collated with the modes of death and other data to help decide those in whom fat embolism caused or contributed to death (fatal cases) and those in whom fat embolism reached clinical significance but was not fatal.

\section{Patients, Material, and Methods}

Frozen sections of lung, kidney, and brain were examined for fat emboli in those who came to necropsy among 854 fractured hip cases admitted between January 1967 and August 1971. The study was retrospective up to December 1970 and prospective after that. To supplement the numbers, tissues were also examined from necropsies in 1966 following Thompson's and Moore's operations. 